\title{
Botanical Materials from the Griffin Mound (41UR142) and Underwood (41CP230) Sites
}

J. Phil Dering

Unknown

Follow this and additional works at: https://scholarworks.sfasu.edu/ita

Part of the American Material Culture Commons, Archaeological Anthropology Commons, Environmental Studies Commons, Other American Studies Commons, Other Arts and Humanities Commons, Other History of Art, Architecture, and Archaeology Commons, and the United States History Commons

Tell us how this article helped you.

This Article is brought to you for free and open access by the Center for Regional Heritage Research at SFA ScholarWorks. It has been accepted for inclusion in Index of Texas Archaeology: Open Access Gray Literature from the Lone Star State by an authorized editor of SFA ScholarWorks. For more information, please contact cdsscholarworks@sfasu.edu. 


\section{Botanical Materials from the Griffin Mound (41UR142) and Underwood (41CP230) Sites}

\section{Creative Commons License}

\section{(c) (1) \&}

This work is licensed under a Creative Commons Attribution-NonCommercial 4.0 International License 


\title{
BOTANICAL MATERIALS FROM THE GRIFFIN MOUND (41UR142) AND UNDERWOOD (41CP230) SITES
}

\author{
J. Phil Dering
}

\section{INTRODUCTION}

This article presents the results of the macrobotanical analysis of samples from two Caddoan archaeological sites in Northeast Texas. Two flotation samples and 34 screen samples were examined from 41UR 142, the Griffin Mound site, a Middle Caddoan settlement located on a tributary of Little Cypress Creek (Nelson et al. 1996). Fifteen finescreen samples were examined from 41CP230, the Underwood site. The screen samples from the Underwood site were recovered from a Late Caddoan Titus phase midden on Big Cypress Creek, in the Lakc Bob Sandlin area (Nelson et al. n.d.).

\section{METHODS}

Standard archaeobotanical laboratory protocol was followed for the botanical analysis of the flotation and screen samples. Flotation samples consist of archaeological sediments that have been floated in water to separate lighter charred plant remains from heavier material, or clays/silts that can be suspended in water and rinsed out of the sample. 'The samples were floated by Bo Nelson (Archeological \& Environmental Consultants), and the light and heavy fractions were submitted to the author for analysis. In addition, some macroplant samples, labeled as screen samples, were submitted for identification. Screen samples often include plant material collected from archaeological screens, recovered in situ during excavation, or picked from sieve screens during laboratory analysis. For the sake of simplification, I have subsumed all of these under the single term "macroplant sample."

\section{SORTING PROCEDURES}

Standard archaeobotanical laboratory procedures werc followed during analysis. The light and heavy fractions of each flotation sample were sorted separately through a series of four nested geological screens with mesh sizes of $4 \mathrm{~mm}, 2 \mathrm{~mm}, 1 \mathrm{~mm}$, and 0.450 $\mathrm{mm}$. The material caught on all of the sieve levels, including the pan, was scanned for floral parts, fruits, and seeds. These objects were identified and counted as they were encountered. Wood and nutshell caught on the $2 \mathrm{~mm}$ and $4 \mathrm{~mm}$ screens was sorted, identified, counted, and weighed. Because many of the macrobotanical/screen lots containcd several specimens representing more than one taxon, the larger samples were passed through nested sieves before sorting and identification.

\section{Identification}

Identification of all carbonized wood was accomplished by using the snap technique, examining them at 8 to 45 magnifications with a hand lens or a binocular dissecting microscope, and comparing them to samples in the author's possession. All seed identifications were made using reference books and sced collections in the author's possession. 


\section{Reporting}

After sorting and identification were completed, data from the heavy fraction was combined with the material from the light fraction for reporting purposes. Because only two flotation samples were examined, no ubiquity value was reported for the Griffin Mound site. Most archaeobotanists agree that ubiquity values are not valid for assemblages with fewer than five samples, because the presence/absence percentage changes too much with the addition or subtraction of a single sample (Hastorf and Popper 1988). Weights and counts for seeds, maize, wood, and nutshell for the two sites are reported in Tables 1, 2, and 3.

\section{RESULTS}

\section{Griffin Mound (41UR142)}

The results of the Griffin Mound analysis are presented in Tables 1 and 2. The flotation samples measured 10 liters each. I'he two flotation samples from the Griftin Mound site contained hickory nut, acorn shell, thin-shelled hickory that resembled pecan, and oak wood. No evidence of cultivated plants was recovered from the flotation samples. A single wild-type Chenopodium seed fragment was recovered from Unit 6, Level 9 (100$120 \mathrm{~cm}$ bs), in Feature 1 .

Table 1. Flotation samples from Griffin Mound (41 UR 142).

\begin{tabular}{|c|c|c|c|c|c|c|c|}
\hline Sample & Feature & Unit & Level & Taxonomic Name & Part Name & Count & Weight $(\mathrm{g})$ \\
\hline 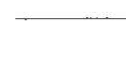 & $-\cdots$ & & $\cdots$ & $--\cdots-$ & - & & \\
\hline 1 & 1 & 5 & 9 & $\begin{array}{l}\text { Carya sp. } \\
\text { Quercus sp. } \\
\text { Thick-shelled Carya } \\
\text { Quercus sp. } \\
\text { Indeterminate Hardwood }\end{array}$ & $\begin{array}{l}\text { Nut } \\
\text { Acorn-shell } \\
\text { Nut } \\
\text { Woxd } \\
\text { Woxud }\end{array}$ & $\begin{array}{l}116 \\
2 \\
1 \\
1 \\
14\end{array}$ & $\begin{array}{l}1.6 \\
0.1 \\
0.1 \\
<0.1 \\
0.2\end{array}$ \\
\hline 2 & 1 & 6 & 9 & $\begin{array}{l}\text { Chenopodium sp. } \\
\text { Thick-shelled Carya } \\
\text { Indeterminate Hardwood }\end{array}$ & $\begin{array}{l}\text { Seed fragment } \\
\text { Nut } \\
\text { Wood }\end{array}$ & $\begin{array}{l}1 \\
91 \\
11\end{array}$ & $\begin{array}{l}<0.1 \\
1.3 \\
0.1\end{array}$ \\
\hline
\end{tabular}

Likewise, the 34 screen samples (all from 1/4-inch mesh) contained much evidence of nut processing, but no remains of cultigens. Acorn endosperm (nut meat) was noted in four midden samples, from Unit 6, Levels $4(40-50 \mathrm{~cm} \mathrm{bs})$ and $7(70-80 \mathrm{~cm} \mathrm{bs})$, Unit 7 , Level $2(20-30 \mathrm{~cm}$ bs), and Unit 8, Level $6(60-70 \mathrm{~cm} \mathrm{bs})$. Acom shell fragments were recovered from Feature 1 in Unit 5 , Level $9(90-100 \mathrm{~cm}$ bs). Hickory nutshell was noted in all of the samples. The material was uniformly large, probably due to the size of the screen from which is was recovered. 
Table 2. Screen samples from Griffin Mound (41UR 142).

\begin{tabular}{|c|c|c|c|c|c|c|}
\hline Feature & Unit & Depth below surface & Taxon & Part & Count & Weight $(\mathrm{g})$ \\
\hline \multirow[t]{5}{*}{ - } & -- & & $-\ldots$ & - & & - \\
\hline & 5 & $50-60 \mathrm{~cm}$ & Carya sp. & Nut & 4 & 0.4 \\
\hline & 5 & $60-70 \mathrm{~cm}$ & Carya sp. & Nut & 6 & 0.5 \\
\hline & 5 & $70-80 \mathrm{~cm}$ & Carya sp. & Nut & 16 & 1.4 \\
\hline & 5 & $80-90 \mathrm{~cm}$ & Carya sp. & Nut & 16 & 1.6 \\
\hline 1 & 5 & $90-100 \mathrm{~cm}$ & Carya sp. & Nut & 19 & 3.4 \\
\hline 1 & 5 & $100-110 \mathrm{~cm}$ & Carya sp. & Nut & 11 & 1.5 \\
\hline \multirow[t]{13}{*}{1} & 5 & $110-130 \mathrm{~cm}$ & Ulmus sp. & Wood & 1 & 0.3 \\
\hline & & & Carya sp. & Nut & 9 & 0.2 \\
\hline & 6 & (0-20 cm & Carya sp. & Nut & 2 & 0.1 \\
\hline & 6 & $20-30 \mathrm{~cm}$ & Carya sp. & Nut & 8 & 0.7 \\
\hline & 6 & $30-40 \mathrm{~cm}$ & Carya sp. & Nut & 10 & 0.8 \\
\hline & 6 & $40-50 \mathrm{~cm}$ & Carya sp. & Nut & 21 & 2.2 \\
\hline & & & Quercus sp. & $\begin{array}{l}\text { Acom } \\
\text { endosper }\end{array}$ & $\mathrm{I}$ & 0.5 \\
\hline & 6 & $50-60 \mathrm{~cm}$ & Carya sp. & Wond & 1 & 0.1 \\
\hline & & & Acer sp. & Wood & 3 & 0.2 \\
\hline & & & Carya sp. & Nut & 24 & 2.7 \\
\hline & 6 & $60-70 \mathrm{~cm}$ & Carya sp. & Nut & 38 & 4.4 \\
\hline & 6 & $70-80 \mathrm{~cm}$ & Quercus sp. & $\begin{array}{l}\text { Acom } \\
\text { endosper }\end{array}$ & 2 & 4.6 \\
\hline & & & Carya sp. & Nut & 41 & 3.9 \\
\hline 1 & 6 & $80-100 \mathrm{~cm}$ & Carya sp. & Nut & 46 & 8.0 \\
\hline 1 & 6 & $100-120 \mathrm{~cm}$ & Carya sp. & Nut & 57 & 6.3 \\
\hline \multirow[t]{10}{*}{1} & $6 / 7 / 8$ & $120-162 \mathrm{~cm}$ & Carya sp. & Nut & 119 & 10.7 \\
\hline & 7 & $0-20 \mathrm{~cm}$ & Carya sp. & Nut & 2 & 0.1 \\
\hline & 7 & $20-30 \mathrm{~cm}$ & Carya sp. & Nut & 6 & 0.5 \\
\hline & & & Quercus sp. & $\begin{array}{l}\text { Acom } \\
\text { endosper }\end{array}$ & 1 & 0.2 \\
\hline & 7 & $30-40 \mathrm{~cm}$ & Carya sp. & Nut & 6 & 0.6 \\
\hline & 7 & $40-50 \mathrm{~cm}$ & Carya sp. & Nut & 16 & 2.5 \\
\hline & 7 & $50-60 \mathrm{~cm}$ & Carya sp. & Nut & 16 & 2.0 \\
\hline & 7 & $60-70 \mathrm{~cm}$ & Quercus sp. & Wood & 3 & 2.3 \\
\hline & & & Carya sp. & Nut & 15 & 1.7 \\
\hline & 7 & $70-80 \mathrm{~cm}$ & Carya sp. & Nut & 22 & 1.9 \\
\hline 1 & 7 & $80-100 \mathrm{~cm}$ & Carya sp. & Nut & 25 & 2.2 \\
\hline \multirow[t]{8}{*}{1} & $7 / 8$ & $100-120 \mathrm{~cm}$ & Carya sp. & Nut & 79 & 7.5 \\
\hline & 8 & $20-30 \mathrm{~cm}$ & Carya sp. & Nut & 5 & 0.4 \\
\hline & 8 & $30-40 \mathrm{~cm}$ & Carya sp. & Nut & 11 & 1.0 \\
\hline & 8 & $40-50 \mathrm{~cm}$ & Carya sp. & Nut & 18 & 1.6 \\
\hline & 8 & $50-60 \mathrm{~cm}$ & Carya sp. & Nut & 17 & 1.7 \\
\hline & & & Quercus sp. & Wood & I & 0.1 \\
\hline & 8 & 6()$-70 \mathrm{~cm}$ & Quercus sp. & $\begin{array}{l}\text { Acorn } \\
\text { endosper }\end{array}$ & 1 & 0.1 \\
\hline & & & Carya sp. & Nut & 21 & 2.3 \\
\hline
\end{tabular}


Table 2. Screen samples from Griffin Mound (41UR142), cont.

\begin{tabular}{|c|c|c|c|c|c|c|}
\hline Feature & Unit & Depth below surface & Taxon & Part & Count & Weight (g) \\
\hline \multirow{3}{*}{1} & 8 & $70-80 \mathrm{~cm}$ & Carya sp. & Nut & 26 & 2.9 \\
\hline & 8 & $80-100 \mathrm{~cm}$ & Carya sp. & Nut & 66 & 9.2 \\
\hline & ST 3 & $40-60 \mathrm{~cm}$ & Carya sp. & Nut & 2 & 0.2 \\
\hline
\end{tabular}

Four wood types were noted in the flotation and screen samples: hickory, maple, oak, and elm. Wood was not very abundant in any of the samples, and accounted for only $0.4 \mathrm{~g}$ of the total weight of $3.5 \mathrm{~g}$ of carbonized material recovered from the two flotation samples.

The samples from the Griffin Mound site suggest that Feature 1 was associated with nutshell processing. The fcature may have been a dump area for the cleaning out of hearths. The lack of cultigens is puzzling, but may be due to the small number of analyzed flotation samples, and to the fact that the screen samples were collected from coarse-mesh screens.

\section{UNDERWOOD (41CP230)}

The 15 fine-screen samples from the Underwood site contained much more interesting material than the material from Griffin Mound (Table 3). Maize cupule or kernel fragments were noted in five of the 15 screen samples (33\%). Two maize kernels were recovered, one from Lot 29 (Unit 10, 10-20 cm bs) and one from Lot 40 (Unit 14, 10-20 $\mathrm{cm}$ bs). A single whole maize cupule was noted in Lot 22 (Unit 8, 5-15 cm bs), and cupule fragments were recovered from Lots 37 (Unit 13, 10-20 cm bs), 40 (Unit 14, 10-20 cm bs), and 54 (Unit 20, 0-10 cm bs).

Table 3. Screen samples from the Underwood Site (41CP230).

\begin{tabular}{lllll} 
I 0 t & Taxon & Part & Count & Weight $(\mathrm{g})$ \\
\hline 11 & Carya sp. & Nut & 1 & 0.2 \\
13 & Thick-shelled Carya & Nut & 1 & 0.3 \\
22 & Quercus sp. & Wood & 1 & $<0.1$ \\
& Zea mays & Cupule & 1 & $<0.1$ \\
& Carya sp. & Nut & 67 & 1.6 \\
24 & Ulmus sp. & Wood & 3 & 0.2 \\
29 & Uncarbonized Seed & Seed & 3 & $<0.1$ \\
31 & Zea mays & Kernel & 1 & 0.1 \\
34 & Carya sp. & Nut & 1 & 0.1 \\
& Quercus sp. & Wood & 1 & 0.1 \\
37 & Thick-shelled Carya & Nut & 1 & $<0.1$ \\
& Zea mays & Cupule & 2 & 1.7 \\
& Carya sp. & Nut & 62 & 0.5
\end{tabular}


Table 3. Screen samples from the Underwood Site (41CP230), cont.

\begin{tabular}{lllll}
\hline Lol & Taxon & Part & Count & Weight $(\mathrm{g})$ \\
\hline 40 & Thin-shelled Carya & Nut & 3 & 0.2 \\
& Zea mays & Kernel & 1 & $<0.1$ \\
& Zea mays & Cupule & 2 & $<0.1$ \\
& Thick-shelled Carya & Nut & 58 & 4.7 \\
& Quercus sp. & Wood & 27 & 0.6 \\
43 & Carya sp. & Nut & 1 & 0.2 \\
48 & Carya sp. & Wood & 1 & 0.2 \\
49 & Quercus sp. & Wood & 2 & 0.3 \\
50 & Carya sp. & Nut & 1 & 0.2 \\
52 & Carya sp. & Wood & 1 & 0.2 \\
54 & Thick-shelled Carya & Nut & 93 & 3.4 \\
& Zea mays & Cupule & 3 & $<0.1$ \\
& Quercus sp. & Wood & 43 & 1.4 \\
\hline
\end{tabular}

Nut remains were present in 11 of the 15 samples $(73 \%)$, and totaled 289 fragments weighing $12.7 \mathrm{~g}$. Both thick-shelled hickory nut fragments and thin-shelled nut fragments that compared favorably to pecan were noted in the samples. Wood charcoal fragments, including hickory, oak, and elm, were recovered in nine of the samples. Although most of the samples contained less than $0.2 \mathrm{~g}$ of wood, Lots 40 and 54 contained larger quantities of wood, all oak.

\section{CONCLUSIONS}

Plant remains from the Griffin Mound site (4IUR142) indicate that nut resources, and possibly pigweed (Chenopodium) were utilized and processed at that location. Given its Middle Caddoan age, the lack of cultigens is puzzling. This may be due to preservation and collection bias, howevcr, because it is not uncommon to recover only very small plant fragments, including maize cob fragments from Caddoan sites of this age in Northeast Texas. If only cupules and kcrncls were present, all material of that size would have passed through a 1/4-inch mesh screen. Cultigens, if present, should have been noted in the flotation samples, but the analysis of only two samples from a site does not make a strong argument for the absence of cultigens.

Plant remains from the Underwood site (4ICP230) indicate the presence of maize, pecan (cf.), and hickory nuts. Although only a minute amount of maize was observed, it was noted in five of the 35 samples. The single complete cupule measured $0.38 \mathrm{~mm}$ deep and the cupule anglc measured $65^{\circ}$, suggesting a 12 -row cob. However, a single cupule is not a reliable measure of cob morphology. Taken as a whole, the plant remains from the Underwood site indicate a mixed economy that relied on both wild and cultivated plants, a common occurrence for Late Caddoan sites. The importance of the forest mast resources has been emphasized in the ethnohistoric literature, but its prominence in the archeological record is due to the durable nature of the nut fragments and the fact that nuts were recycled as fuel in campfires. 


\section{REFERENCES CITED}

Hastorf, C. and V. Popper (editors)

1988 Current Paleoethnobotany: Analytical Methods and Cultural Interpretations of Archaeological Plant Remains. University of Chicago Press, Chicago.

Nelson, B., M. Turner, and T. K. Perttula

1996 Archacological Investigations at the Griffin Mound Sitc: A Middle Caddoan Site in Upshur County, Texas. The Cache, Collected Papers on Texas Archeology, No. 3:49-67. Office of the State Archeologist, Texas Historical Commission, Austin.

Nelson, B., T. K. Perttula, J. P. Dering, and L. Schniebs

n.d. The Underwood Site (41C230), a Late Caddoan Titus Phase Settlement along Big Cypress Creek, Camp County, Texas. MS in preparation. 